\title{
In vitro Callus Induction and Regeneration of Popular Indica Rice Genotypes
}

\author{
Aananthi. $\mathrm{N}^{* 1}$ and C.R. Anandakumar ${ }^{2}$ \\ ${ }^{1}$ Department of Plant Breeding and Genetics, AC \&RI, TNAU, Killikulam, India \\ ${ }^{2}$ Tamil Nadu Agricultural University, Coimbatore, India \\ *Corresponding author: aananthi.n@tnau.ac.in (ORCID ID: 0000-0003-4928-2662)
}

Paper No. 860

Received: $19-08-2020$

Revised: $18-11-2020$

Accepted: 07-12-2020

\begin{abstract}
Five rice cultivars viz., ASD 16, White Ponni, Pusa Basmati 1, Pusa Sugandh 4 and Pusa Sugandh 5 belonging to subspecies indica were compared for its ability in callus formation and regeneration. In this experiment, the different parameters viz., the effect of hormones (2,4-D and kinetin), organic supplement (coconut milk O1-CM 100 mll-1, O2-CM 75 mll-1, O3-CM 50 mll-1), explants (seed and immature embryo), media (MS and N6), carbon source (sucrose and maltose) using five genotypes on callus response was studied. The effect of hardening methods was also assessed. Results showed that for enhanced callus induction was with MS medium supplemented with $2.0 \mathrm{mgl}^{-1}$ 2, 4-D + $0.5 \mathrm{mgl}^{-1}$ kinetin $+30 \mathrm{gl}^{-1}$ maltose irrespective of explants used. Addition of $100 \mathrm{ml} \mathrm{l}^{-1}$ coconut milk was found have improvement in callus response. The performance of immature embryo was better than seed for callus induction, emrbyogenic callus formation, rhizogenic callus formation and regeneration. MS media provided superiority over N6. Among the genotypes Pusa Basmati 1 rendered outstanding performance in callus behavior. The

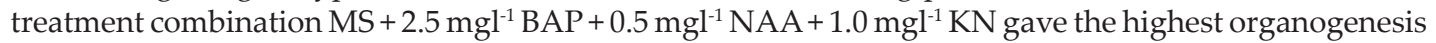
response and regeneration of plantlets. Hardening in mist chamber was recognized as the best method to give the highest per cent of regenerated plant lets.
\end{abstract}

\section{Highlights \\ 0 Five indica rice varieties were used for callus induction and regeneration \\ 0 MS +2.0 $\mathrm{mgl}^{-1} 2,4-\mathrm{D}+0.5 \mathrm{mgl}^{-1} \mathrm{kinetin}^{+} 30 \mathrm{gl}^{-1}$ maltose gave enhanced callus induction.



Keywords: Callus induction, Indica rice, immature embryo, regeneration

Rice, Oryza sativa L. $(2 \mathrm{n}=2 \mathrm{x}=24)$, an annual grass, belonging to the family Poaceae, is the staple food for the people of India and World's most important cereal crop after wheat and maize (Ray 1985). It provides half of total dietary carbohydrate, especially in Asian countries and it is suitable diet for more than three billion people, supplying $50-80 \%$ of their daily calorie intake (Kush 2005). A considerable improvement has been done through traditional rice breeding. Rice breeding has made significant progress towards higher yield, improved quality, greater disease resistance and other important characters of agricultural importance in the past and even in future, it will still play an important role (Sun et al. 1990). Several laboratories have described regeneration of plants through callusing from different rice explants such as immature embryos, immature panicles (Ling et al. 1983), young inflorescence (Chen et al. 1985) and root (Abe and Futsuharah 1985). In rice, there are reports on successful plant regeneration from explants such as coleoptile, root tips, immature

How to cite this article: Aananthi, N. and Anandakumar, C.R. 2020. In vitro Callus Induction and Regeneration of Popular Indica Rice Genotypes. IJAEB, 13(4): 383-393.

Source of Support: None; Conflict of Interest: None $\odot$ 
embryos, leaf blades, leaf segments and other parts of O. sativa (Diawuoh et al. 2017) and Diawuoh et al. (2017) conducted experiments with the aim of developing a protocol for callus induction and plantlet regeneration in vitro from leaf segments of three accessions of African rice (O. glaberrima Steud.) indigenous to Ghana.

Plant tissue culture plays an important role in the production of agricultural and horticultural plants and in the manipulation of plants for improved agronomic performance. In vitro culture of plant cells and tissues has attracted considerable interest in recent years because it provides the means to study the physiological and genetic processes of plants in addition to offering the potential to assist in breeding improved cultivars increasing their genetic variability. Regenerated plants are expected to have the same genotype as the donor plant; however, in some cases, somaclonal variants are found among regenerated plants, e.g. in rice. The composition of the medium, mainly the hormonal balance, is another important factor influencing in vitro culture initiation and plant regeneration from somatic embryos. The auxin 2, 4-dichlorophenoxyacetic acid (2, 4- D), alone or in combination with cytokinins, is widely used to enhance callus induction and maintenance. Genetic factors are considered a major contributor to the in vitro response of cultured tissues. Differences in the production of embryogenic calli and regenerated plantlets have been observed, depending on the genotype and explant source. Therefore, plant regeneration from callus culture could provide useful germplasm for plant breeding programmes (Rabha et al. 2018).

Genetic manipulation provides an useful adjunct to conventional breeding approaches (Vasil 1995). Solving this problem will entail development of rice varieties with higher yields, excellent grain quality and resistance to biotic and abiotic stresses. Before targeting a particular rice cultivar to in vitro genetic manipulation, we need to have an efficient regeneration of green fertile plants from explant tissues. Indica and Japonica are the two major subspecies of rice grown in different regions of the world. Indica rice (long grain tropical rice) alone accounts for approximately 80 per cent of the cultivated rice. Indica rice is sensitive to several biotic (yellow stem borer, stripped stem borer, leaf folders, blast and blight) and abiotic (drought and salinity) stresses and is a poor yielder. Wide difference exists between their tissue culturability. The indica being less responsive than japonica types. Thus it is important to establish parameters for the transformation of popular Indica varieties (Visarada et al. 2002 and Tiyagi et al. 2007). Successful callus induction from rice seed has been reported by several researchers (Abiramasundari et al. 2015 and Upadhyaya et al. 2015) in some varieties. An improved method for callogenesis was reported by Rashid et al. (2000).

Therefore, this study was aimed to evaluate these five rice varieties for callus induction and regeneration efficiency under different concentrations and combinations of growth regulators and different parameters. The objectives of this study were to find a suitable medium and culture condition for callus induction and regeneration and this will also be useful for indica cultivar improvement for various traits through tissue culture and gene transfer studies.

\section{MATERIALS AND METHODS}

The experiment was conducted at the Tissue Culture Laboratory, Department of Plant Breeding and Genetics, Agricultural College and Research Institute, Madurai. The rice genotypes chosen for the study included ASD 16, White Ponni, Pusa Basmati 1, Pusa Sugandh 4 and Pusa Sugandh 5. The specifications of the rice genotypes used were given in Table 1.

Preliminary culture studies included standardization of medium with five genotypes for induction of callus by culturing two types of explants using different media. Callus response was assessed by varying the levels of both growth hormones and carbon source. The media for the seed explants used were as follows $\mathrm{S} 1=\mathrm{MS}$ basal $+30 \mathrm{gl}^{-1}$ sucrose, M1 $=\mathrm{MS}$ basal $+30 \mathrm{~g} \mathrm{l}^{-1}$ maltose, S1D1 $=\mathrm{MS}$ basal +2 $\mathrm{mg} \mathrm{l}^{-1}$ 2, 4- D + $30 \mathrm{~g} \mathrm{l}^{-1}$ sucrose, M1D1 = MS basal + $2 \mathrm{mg} \mathrm{l}^{-1} 2$, 4- D + $30 \mathrm{~g} \mathrm{l}^{-1}$ maltose, $1 \mathrm{D} 1 \mathrm{~K}=\mathrm{MS}$ basal $+2 \mathrm{mg} \mathrm{l}^{-1} 2,4-\mathrm{D}+0.5 \mathrm{mg} \mathrm{l}^{-1} \mathrm{kin}+30 \mathrm{~g} \mathrm{l}^{-1}$ sucrose , S60D1K1 = MS basal $+2 \mathrm{mg} \mathrm{l}^{-1} 2,4-\mathrm{D}+$ kin $0.5 \mathrm{mg}$ $\mathrm{l}^{-1}+60 \mathrm{~g} \mathrm{l}^{-1}$ sucrose, M1D1K1 $=$ MS basal $+2 \mathrm{mg} \mathrm{l}^{-1}$ 2, 4- D + $0.5 \mathrm{mg} \mathrm{l}^{-1} \mathrm{kin}+30 \mathrm{~g} \mathrm{l}^{-1}$ maltose, S1D1B1= MS basal $+2 \mathrm{mg} \mathrm{l}^{-1} 2,4-\mathrm{D}+0.5 \mathrm{mg} \mathrm{l}^{-1} \mathrm{BAP}+30 \mathrm{~g} \mathrm{l}^{-1}$ sucrose, $\mathrm{N} 6=\mathrm{N} 6$ basal $+2 \mathrm{mg} \mathrm{l}^{-1} 2,4-\mathrm{D}+$ kin 0.5 $\mathrm{mg} \mathrm{l}^{-1}+30 \mathrm{~g} \mathrm{l}^{-1}$ sucrose and the treatments using 
Table 1: Specifications of selected rice varieties

\begin{tabular}{|c|c|c|c|c|c|}
\hline Sl. No. & Genotype & Pedigree & Origin & $\begin{array}{l}\text { Duration } \\
\text { (Days) }\end{array}$ & $\begin{array}{l}\text { Salient features and } \\
\text { grain shape }\end{array}$ \\
\hline 01 & ASD $16\left(G_{1}\right)$ & ADT 31/CO39 & RRS Ambasamudram & $110-115$ & $\begin{array}{l}\text { Non aromatic } \\
\text { Short Bold }\end{array}$ \\
\hline 02 & White Ponni $\left(G_{2}\right)$ & $\begin{array}{l}\text { Taichung 65/2 } \\
\text { Mayong Ebos-80. }\end{array}$ & Coimbatore & 140 & $\begin{array}{l}\text { Non aromatic } \\
\text { Short Bold }\end{array}$ \\
\hline 03 & Pusa Basmati $1\left(\mathrm{G}_{3}\right)$ & Pusa 150/ Karnal local & $\begin{array}{l}\text { IARI } \\
\text { New Delhi }\end{array}$ & 135 & $\begin{array}{l}\text { Aromatic } \\
\text { Long Slender }\end{array}$ \\
\hline 04 & Pusa Sugandh $4\left(\mathrm{G}_{4}\right)$ & $\begin{array}{l}\text { Pusa 614-1-2/ } \\
\text { Pusa614-2-4-3. }\end{array}$ & $\begin{array}{l}\text { IARI } \\
\text { New Delhi }\end{array}$ & $140-145$ & $\begin{array}{l}\text { Aromatic } \\
\text { Long Slender }\end{array}$ \\
\hline 05 & Pusa Sugandh $5\left(G_{5}\right)$ & $\begin{array}{l}\text { Pusa 3A / } \\
\text { Haryana Basmati }\end{array}$ & $\begin{array}{l}\text { IARI } \\
\text { New Delhi }\end{array}$ & $125-130$ & $\begin{array}{l}\text { Aromatic } \\
\text { Long Slender }\end{array}$ \\
\hline
\end{tabular}

MS media for the immature embryo explants are given as S2D2= MS basal + $2 \mathrm{mg} \mathrm{l}^{-1} 2,4-\mathrm{D}+30 \mathrm{~g} \mathrm{l}^{-1}$ sucrose, M2D2 = MS basal $+2 \mathrm{mg} \mathrm{l}^{-1} 2,4-\mathrm{D}+30 \mathrm{~g} \mathrm{l}^{-1}$ maltose, S2D2K2 = MS basal $+2 \mathrm{mg} \mathrm{l}^{-1} 2,4-\mathrm{D}+0.5$ $\mathrm{mg} \mathrm{l}^{-1} \mathrm{Kin}+30 \mathrm{~g} \mathrm{l}^{-1}$ sucrose and M2D2K2 = MS basal $+2 \mathrm{mg} \mathrm{l}^{-1} 2,4-\mathrm{D}+0.5 \mathrm{mg} \mathrm{l}^{-1} \mathrm{Kin}+30 \mathrm{~g} \mathrm{l}^{-1}$ maltose. Different concentrations of organic supplements like coconut milk (CM) was added with the best combination of hormones to study the influence of organic supplements on callus response and the concentrations used were as follows O1-CM 100 $\mathrm{mll}^{-1}$, O2-CM $75 \mathrm{mll}^{-1}$, O3-CM $50 \mathrm{mll}^{-1}$.

\section{Explant preparation and incubation}

The mature seeds of paddy were dehusked manually prior to surface sterilization. The seeds were washed 2 to 3 times with sterile distilled water to remove any impurity present. This was done under aseptic conditions. The seeds were then surface sterilized with 70 per cent ethanol for $120 \mathrm{sec}$ followed by 0.1 per cent mercuric chloride solution for $6-8 \mathrm{~min}$. The seeds were then rinsed 3 to 4 times thoroughly with sterile distilled water. Surface sterilized seeds were inoculated under aseptic conditions, in the callus induction medium and direct embryo contact with the medium was avoided. Similarly, the immature embryos were collected from the healthy and disease free plant when the seeds were in milky stage. The stage was identified by pressing the spikelet in between thumb and fore finger and the milky ooze coming out of the spikelet indicated the correct stage for collecting immature embryos. The spikelets were dissected and the immature embryos were taken out under aseptic condition. Generally in rice genotypes the immature embryos formed 12-14 days after flowering. The callus tubes were incubated under controlled environment conditions in the growth room. The cultures were subjected to light and dark cycle of 16/8 hrs per day. The light (2000 lux) was provided by a cool, white lamp (Philips 40w). The cultures were maintained at a temperature of $25 \pm 20^{\circ} \mathrm{C}$ and 70 per cent relative humidity. For callus initiation, the tubes were kept under dark conditions. Afterwards tubes were taken outside and exposed to light for callus development.

\section{Regeneration and Hardening}

When sufficient calli were obtained, enough embryogenic calli were selected and transferred to regeneration medium with a change in type and concentration of hormones. BAP was tried at 0.5, 1.0, 1.5, $2.0 \mathrm{mg} \mathrm{l}^{-1}$; NAA at 0.5, $1.0 \mathrm{mg} \mathrm{l}^{-1}$ keeping $1.0 \mathrm{mg} \mathrm{l}^{-1}$ of kinetin as constant. In the regeneration medium, growth hormones were combined at various levels to initiate shooting and rooting simultaneously and the treatment combinations were as follows $\mathrm{R} 1=0.5 \mathrm{mg} \mathrm{l}^{-1} \mathrm{BAP}+0.5 \mathrm{mg} \mathrm{l}^{-1}$ $\mathrm{NAA}+1.0 \mathrm{mg} \mathrm{l}^{-1} \mathrm{kin}, \mathrm{R} 2=0.5 \mathrm{mg} \mathrm{l}^{-1} \mathrm{BAP}+1.0 \mathrm{mg}$ $\mathrm{l}^{-1} \mathrm{NAA}+1.0 \mathrm{mg} \mathrm{l}^{-1} \mathrm{kin}, \mathrm{R} 3=1.0 \mathrm{mg} \mathrm{l}^{-1} \mathrm{BAP}+0.5$ $\mathrm{mg} \mathrm{l}^{-1} \mathrm{NAA}+1.0 \mathrm{mg} \mathrm{l}^{-1} \mathrm{kin}, \mathrm{R} 4=1.0 \mathrm{mg} \mathrm{l}^{-1} \mathrm{BAP}+$ $1.0 \mathrm{mg} \mathrm{l}^{-1} \mathrm{NAA}+1.0 \mathrm{mg} \mathrm{l}^{-1} \mathrm{kin}, \mathrm{R} 5=1.5 \mathrm{mg} \mathrm{l}^{-1} \mathrm{BAP}$ $+0.5 \mathrm{mg} \mathrm{l}^{-1} \mathrm{NAA}+1.0 \mathrm{mg} \mathrm{l}^{-1} \mathrm{kin}, \mathrm{R} 6=1.5 \mathrm{mg} \mathrm{l}^{-1}$ $\mathrm{BAP}+1.0 \mathrm{mg} \mathrm{l}^{-1} \mathrm{NAA}+1.0 \mathrm{mg} \mathrm{l}^{-1} \mathrm{kin}, \mathrm{R} 7=2.0 \mathrm{mg}$ $\mathrm{l}^{-1} \mathrm{BAP}+0.5 \mathrm{mg} \mathrm{l}^{-1} \mathrm{NAA}+1.0 \mathrm{mg} \mathrm{l}^{-1} \mathrm{kin}, \mathrm{R} 8=2.0 \mathrm{mg}$ $\mathrm{l}^{-1} \mathrm{BAP}+1.0 \mathrm{mg} \mathrm{l}^{-1} \mathrm{NAA}+1.0 \mathrm{mg} \mathrm{l}^{-1} \mathrm{kin}$.

Young plantlets with good shoot and root growth were taken out of the tubes for hardening. Various hardening procedures tried were as follows. 


\section{(i) Hardening in soil in plastic cups (H1)}

The plantlets were washed free of adhering agar and directly planted in small plastic cups containing autoclaved potting mixture, plants were kept under culture conditions for one week and at room temperature for another one week and plants were transferred to mud pots.

\section{(ii) Hardening in water followed by soil with poly bags (H2)}

The plantlets were washed repeatedly to remove adhering agar and kept in water for three days under culture conditions. Plantlets were then transferred into small plastic cups containing autoclaved potting mixture and covered with poly bags to check evapotranspiration loss (Biswas and Mandal 1999). For one week plantlets were allowed to be under culture conditions and later for another one week at room temperature. Poly bags were removed and plantlets were transferred to mud pots.

\section{(iii) Hardening in water followed by mist chamber (H3)}

Adhering agar was removed by washing repeatedly and the plants were kept in water for three days under culture conditions and then kept in mist chamber at a temperature that was 10 to $30^{\circ} \mathrm{C}$ less than local outer temperature and at $\mathrm{RH}$ of 90 per cent, in small cups for one week. Then plants were transferred to mud pots.

From the above said treatment using different explants, following parameters of response were computed.

\section{Callus induction per cent}

Number of explants giving callus response was recorded in each treatment and callus induction per cent was worked out as,

1. Callus induction per cent $=$

\section{Number of explants giving callus induction}

Total number of explants inoculated

The embryogenic and rhizogenic calli were assorted before subculture and the percentage of embryogenic calli and rhizogenic calli was calculated as follows
2. Embroyogenic calli percentage $=$

$\frac{\text { Total number of embryogenic calli produced }}{\text { Total number of calli }} \times 100$

3. Rhizogenic calli percentage $=$

$\frac{\text { Total number of rhizogenic calli produced }}{\text { Total number of calli }} \times 100$

4. Regeneration of per explant (\%)

The percentage of plant regeneration was worked out as follows,

Percentage of Regeneration $=$

$$
\frac{\text { Number of plants regenerated }}{\text { Total number of explants inoculated }} \times 100
$$

5. Hardening per cent

Plantlets which survived after transfer to field conditions were considered as hardened plantlets and hardening per cent was calculated as,

Hardening per cent $=$

$$
\frac{\text { Number of hardened plantlets }}{\text { Number of plantlets kept for hardening }} \times 100
$$

\section{STATISTICAL ANALYSIS}

The observations recorded were statistically analyzed by subjecting the data to Factorial Completely Randomized Design (Gomez and Gomez 1984). Level of significance was determined by using standard analysis of variance (ANOVA) (Panse and Sukhatme, 1964).Differences among mean values were assessed by LSD (Least Significant Difference). The data obtained with per cent values were subjected to arc sine transformation (where ever necessary ) and analysed using the statistical software AGRES.

\section{RESULTS AND DISCUSSION}

Callus induction and plant regeneration from callus need homogenous population of totipotent and embryogenic cells (Agrawal et al. 2006). The potential for callus formation and regeneration have been reported to be varietal characteristics and efficient regeneration in indica rice still poses a major problem for genetic manipulation through innovative approaches (Saharan et al. 2004). While it has been possible to obtain high plant regeneration 
frequencies in japonica rice varieties, the success for reproducible fertile regeneration has been limited in indica rice varieties. As a result progress towards the transfer of useful genes into indica rice has been slow. Wide differences existed between the tissue culturability of the two sub species viz., indica and japonica. It is important to establish parameters for the transformation of popular indicia rice varieties (Visarada et al. 2002 and Tyagi et al. 2007). Availability of an efficient regeneration system is a prerequisite for undertaking any transformations study. The optimum media composition and other culture condition are required for efficient plant regeneration (Khanna and Raina, 1997 and Saharan et al. 2004). Agrobacterium- based transformation of rice, needs efficient regeneration systems, including highly responsive indica genotypes as well as culture conditions are critical factors to be identified and standardized.

Therefore, the present investigation is performed to standardize the tissue culture technique with respect to media composition, genotype, explant, hormonal combination, regeneration and hardening.

\section{Effect of explant}

The selection of explant plays an important role in successful callus induction and plant regeneration. In the present study seed and immature embryo were used as explants and the performance of immature embryo was better than seed explant in forming profuse and embryogenic callus and this observation is in accordance with previous findings reported by Aldemita and Hodges (1996), Sudha (2000), Vinothini (2004). The present study revealed that even explants from a single genotype do not respond identically in culture. For example seed explant of Pusa Basmati 1 gave 62.82 per cent callus induction and immature embryo explant of the same genotype gave 75.55 per cent callus induction. Most likely it was due to the varying gradients of endogenous hormones. Similar observations were reported by (Lakshmi Narayanan 1997 and Sudha 2000). Immature embryo explants have proven to be the best source for the establishment of embryogenic callus and plant regeneration. The genetic basis of variability in tissue culture response and morphogenesis is most likely due to differences in hormone metabolism within the explant (Norstog 1970). Immature embryo explant used in this study was taken from 12 and 14 days after pollination to get maximum response. Vasil (1988) also indicated that only explants cultured at a specific developmental stage gave regenerable cultures.

\section{Effect of nutrient media}

Rice callus induction is known to depend on the type of medium used (Zhao 1999 and Lee et al. 2002). The implication of such result is that there may still be room for further modification of the subculture to improve both the growth rate and quality of the calli. In this study, the maximum callus induction per cent was noticed on MS media and it was lower on N6 media .Similar results were already reported by Sudha (2000) and Khaleda and Al-Forkan (2006). In contrast Lee et al. (2002) reported N6 media showed higher callus induction and embryogenic callus formation. Induction of embryogenic calli in rice is considered as the most critical step. These results were in complete agreement with those of (Saharan et al. 2004; Khaleda and Al-Forkan 2006). Thus the results of the present study supplement the earlier reports on the suitability of MS media for callus induction, growth and regeneration of plantlets. The reason for the superiority of standard MS medium may be due to its composition. It is having higher concentrations of nutrients especially macronutrients like $\mathrm{MgSO}_{4} .7 \mathrm{H}_{2} 0\left(370 \mathrm{mg} \mathrm{l}^{-1}\right)$ and $\mathrm{CaCl}_{2} \cdot 2 \mathrm{H}_{2} \mathrm{O}\left(440 \mathrm{mg} \mathrm{l}^{-1}\right)$ when compared to $\mathrm{N}_{6}$ medium. The concentration of micronutrients viz., $\mathrm{MnSO}_{4} .4 \mathrm{H}_{2} \mathrm{O}, \mathrm{ZnSO}_{4^{\prime}} 7 \mathrm{H}_{2} \mathrm{O}, \mathrm{H}_{3} \mathrm{BO}_{3}$ is also higher in MS medium. In $\mathrm{N}_{6}$ medium minor elements like $\left.\mathrm{Na}_{2} \mathrm{MOO}_{4} \cdot 2 \mathrm{H}_{2} \mathrm{O}, \mathrm{CuSO}_{4} \cdot 5 \mathrm{H}_{2}\right)$ and $\mathrm{COCl}_{2} \cdot 6 \mathrm{H}_{2} \mathrm{O}$ are absent. Similar findings were observed by Sudha (2000). Concentration of carbon source in the medium has a determining role in callus induction, organogenesis and embryogenesis (Gupta 1997). This study indicated that the callus induction per cent and embryogenic callus formation was higher at $30 \mathrm{~g} \mathrm{l}^{-1}$ sucrose when compared to 60 $\mathrm{g}^{-1}$ sucrose. The above finding is in conformity with those of Sudha (2000), Saharan et al. (2004), Monirul Islam et al. (2005), Agrawal et al. (2006) and Hoque et al. (2007) also concluded that there was no callus induction without sucrose and callus induction and generation was maximum when the sucrose level was $30 \mathrm{~g} \mathrm{l}^{-1}$ and it decreased with the increased concentration of sucrose. Apart from 
finding the optimum concentration of sucrose, the effect of sucrose and maltose was studied using seed as well as immature embryo explants. In the present study, the embryogenic callus formation was higher on media with maltose in both seed and immature embryo culture (69.12 and 79.78). In accordance to this findings, Kumar et al. (2005) and Zaidi et al. (2006) also reported that formation of embryogenic calli was enhanced with the use of maltose as a carbon source and maltose proved to be the most effective, resulting in the highest frequencies of callus induction, embryogenic calli and regeneration.

\section{Effect of genotype}

In this investigation the seed and immature embryo explants taken from the same genotype did not respond similarly in culture, i.e. immature embryo of Pusa Sugandh 4 recorded the highest per cent of callus induction, while the seed explant gave lowest per cent of callus induction on same growth media. Sudha (2000) and Monirul Islam et al. (2005) also evidenced these findings (Table 2 and 3).

There was a wide difference in embryogenic callus formation exhibited by white ponni in seed culture. But in immature embryo culture Pusa Sugandh 5

Table 2: Comparison of the effect of Kinetin on media with maltose - seed culture ( expressed in per cent)

\begin{tabular}{|c|c|c|c|c|c|c|c|c|}
\hline \multirow{2}{*}{ Genotypes } & \multicolumn{4}{|c|}{ MS + $2 \mathrm{mg} \mathrm{l}^{-1} 2,4-\mathrm{D}+30 \mathrm{~g} \mathrm{l}^{-1}$ Maltose $\mathrm{M}_{1} \mathrm{D}_{1}$} & \multicolumn{4}{|c|}{$\begin{array}{c}\text { MS +2 } \mathrm{mg} \mathrm{l}^{-1} 2,4-\mathrm{D}+0.5 \mathrm{mg} \mathrm{l}^{-1} \mathrm{Kin}+30 \mathrm{gl}^{-1} \\
\text { Maltose } \mathrm{M}_{1} \mathrm{D}_{1} \mathrm{~K}_{1}\end{array}$} \\
\hline & A & B & C & D & A & B & $\mathrm{C}$ & $\mathrm{D}$ \\
\hline$\overline{\mathrm{G}_{1}}$ & 77.87 & 67.35 & 18.77 & 22.95 & 90.48 & 77.61 & 11.89 & 54.02 \\
\hline $\mathrm{G}_{2}$ & 86.84 & 69.12 & 17.82 & 38.29 & 90.62 & 79.63 & 10.09 & 59.04 \\
\hline $\mathrm{G}_{3}$ & 76.45 & 66.32 & 20.08 & 28.10 & 88.24 & 75.99 & 13.11 & 53.63 \\
\hline $\mathrm{G}_{4}$ & 71.07 & 63.17 & 19.91 & 25.23 & 85.11 & 71.16 & 16.11 & 45.18 \\
\hline \multirow[t]{2}{*}{$\mathrm{G}_{5}$} & 60.85 & 53.57 & 27.41 & 14.87 & 71.56 & 65.71 & 18.68 & 23.90 \\
\hline & & & A & B & & C & & \\
\hline \multirow[t]{2}{*}{ Media } & SEd & & 0.13 & 0.14 & & 0.12 & & \\
\hline & $\mathrm{CD}(0.01)$ & & 0.35 & 0.36 & & 0.33 & & \\
\hline \multirow[t]{2}{*}{ Genotype } & SEd & & 0.33 & 0.35 & & 0.31 & & \\
\hline & $\mathrm{CD}(0.01)$ & & 0.89 & 0.93 & & 0.83 & & \\
\hline$M \times G$ & SEd & & 0.47 & 0.50 & & 0.44 & & \\
\hline interaction & $\mathrm{CD}(0.01)$ & & 1.26 & 1.31 & & 1.17 & & \\
\hline
\end{tabular}

Callus induction (A), embryogenic callus formation (B), rhizogenic callus formation (C) and regeneration (D).

Table 3: Comparison of the effect of Kinetin on media with maltose- Immature embryo culture (expressed in per cent)



Callus induction (A), embryogenic callus formation (B), rhizogenic callus formation (C) and regeneration (D). 
Table 4: Comparison of the effect of Kinetin on medium with sucrose and maltose - Immature embryo culture (expressed in per cent)

\begin{tabular}{|c|c|c|c|c|c|c|c|c|}
\hline \multirow{2}{*}{ Genotypes } & \multicolumn{4}{|c|}{$\begin{array}{c}\mathrm{MS}+2 \mathrm{mg} \mathrm{l}^{-1} 2,4-\mathrm{D}+0.5 \mathrm{mg} \mathrm{l}^{-1} \mathrm{Kin}+30 \mathrm{~g} \mathrm{l}^{-1} \\
\text { Sucrose } \mathrm{S}_{2} \mathrm{D}_{2} \mathrm{~K}_{2}\end{array}$} & \multicolumn{4}{|c|}{$\begin{array}{c}\mathrm{MS}+2 \mathrm{mg} \mathrm{l}^{-1} 2,4-\mathrm{D}+0.5 \mathrm{mgl}^{-1} \mathrm{Kin}+30 \mathrm{gl}^{-1} \\
\text { Maltose } \mathrm{M}_{2} \mathrm{D}_{2} \mathrm{~K}_{2}\end{array}$} \\
\hline & $\mathbf{A}$ & B & $\mathrm{C}$ & D & $\mathbf{A}$ & B & $\mathrm{C}$ & D \\
\hline $\mathrm{G}_{1}$ & 81.53 & 69.30 & 16.27 & 47.05 & 86.91 & 75.04 & 15.02 & 48.30 \\
\hline $\mathrm{G}_{2}$ & 76.24 & 76.15 & 19.00 & 14.48 & 71.57 & 69.59 & 17.08 & 16.32 \\
\hline $\mathrm{G}_{3}$ & 86.15 & 74.13 & 1.92 & 54.88 & 91.18 & 79.94 & 9.65 & 58.22 \\
\hline $\mathrm{G}_{4}$ & 96.30 & 87.41 & 4.94 & 63.28 & 99.10 & 89.55 & 3.39 & 66.85 \\
\hline \multirow[t]{2}{*}{$\mathrm{G}_{5}$} & 91.96 & 79.89 & 9.23 & 59.36 & 94.95 & 88.20 & 4.20 & 61.28 \\
\hline & & & & B & & C & & \\
\hline \multirow[t]{2}{*}{ Media } & SEd & & & 0.20 & & 0.19 & & \\
\hline & $\mathrm{CD}(0.01)$ & & & 0.57 & & 0.52 & & \\
\hline \multirow[t]{2}{*}{ Genotype } & SEd & & & 0.39 & & 0.35 & & \\
\hline & $\mathrm{CD}(0.01)$ & & & 1.07 & & 0.97 & & \\
\hline $\mathrm{M} \times \mathrm{G}$ & SEd & & & 0.55 & & 0.50 & & \\
\hline interaction & $\mathrm{CD}(0.01)$ & & & 1.51 & & 1.38 & & \\
\hline
\end{tabular}

Callus induction (A), embryogenic callus formation (B), rhizogenic callus formation $(C)$ and regeneration $(D)$.

Table 5: Performance of genotypes to embryogenic callus formation on different media using seeds (expressed in per cent)

\begin{tabular}{|c|c|c|c|c|c|c|c|}
\hline $\mathrm{C}_{\text {Genotypes }}^{\text {Media }}$ & $\mathrm{S}_{1} \mathrm{D}_{1}$ & $\mathrm{M}_{1} \mathrm{D}_{1}$ & $\mathrm{~S}_{1} \mathrm{D}_{1} \mathrm{~K}_{1}$ & $\mathrm{~S}_{60 \mathrm{D}_{1} \mathrm{~K}_{1}}$ & N6 & $S_{1} D_{1} B_{1}$ & $\mathrm{M}_{1} \mathrm{D}_{1} \mathrm{~K}_{1}$ \\
\hline$\overline{G_{1}}$ & 61.76 & 67.35 & 71.14 & 46.24 & 64.89 & 65.07 & 77.61 \\
\hline $\mathrm{G}_{2}$ & 64.25 & 69.12 & 75.22 & 54.87 & 67.68 & 67.08 & 79.63 \\
\hline $\mathrm{G}_{3}^{2}$ & 55.62 & 66.32 & 70.18 & 44.01 & 63.81 & 65.80 & 75.99 \\
\hline $\mathrm{G}_{4}^{3}$ & 58.34 & 6.17 & 66.44 & 53.05 & 62.70 & 59.51 & 71.16 \\
\hline $\mathrm{G}_{5}^{4}$ & 46.22 & 53.57 & 61.55 & 49.94 & 42.27 & 40.50 & 65.71 \\
\hline
\end{tabular}

\begin{tabular}{llll}
\hline & SEd & CD (0.05) & CD (0.01) \\
\hline Media & 0.36 & 0.072 & 0.96 \\
Genotype & 0.31 & 0.61 & 0.81 \\
M $\times$ G interaction & 0.81 & 1.61 & 2.14 \\
\hline
\end{tabular}

showed maximum per cent of embryogenic callus formation in MS medium with 2,4-D and maltose (Table 5 and 6). These genotypic variations may be attributed to differences in the components and the concentration of the endogenous plant hormones and sensitivity to 2, 4-D between varieties as reported earlier by Agrawal et al. (2006) Hoque et al. (2007) and Monirul Islam et al. (2005). Katiyar et al. (1999) also concluded that callus induction and plant regeneration were found to be greatly influenced by the genotypes and 2, 4-D concentration in media, it was also noted there was reduction in regeneration in the genotypes White ponni, and ASD 16. In accordance to this finding, Sumathi (1992) concluded that conditions optimal for plant regeneration in one cultivar fail to produce plants in another cultivar of the same species (Table $6)$.

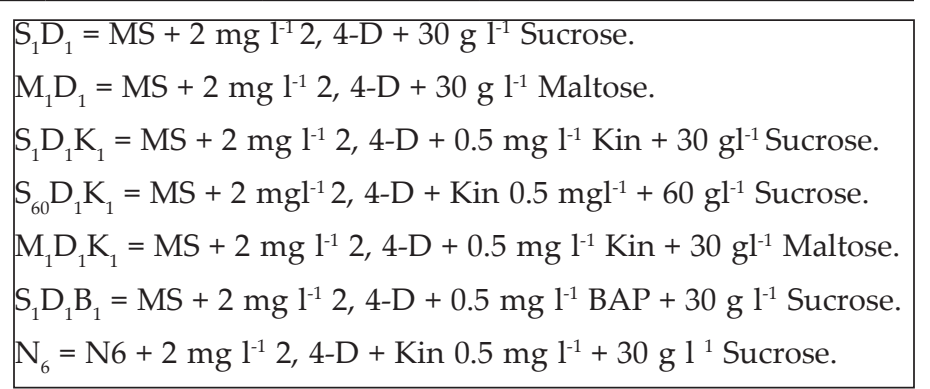

\section{Effect of growth regulators}

Plant growth regulators are the critical media components in determining the developmental pathway of plant cells. Addition of 2, 4-D induced callus development and also stated that the presence of 2, 4-D in the culture medium is critical for rice callus induction from mature seeds and formation of embryogenic callus. In this experiment, the addition of 2, 4-D (2.0 mgl-1) was found to induce good callus growth in MS medium and percentage of embryogenic callus formation was higher when 2, 4- D (2 $\left.\mathrm{mg} \mathrm{l}^{-1}\right)$ was combined with maltose (30 g $\left.\mathrm{l}^{-1}\right)$ than with sucrose $\left(30 \mathrm{~g} \mathrm{l}^{-1}\right)$. This findings was in confirmation with earlier reports by Azhakanandam 
Table 6: Performance of genotypes on different media using immature embryo ( expressed in per cent)

\begin{tabular}{|c|c|c|c|c|c|c|c|c|c|c|c|c|c|c|c|c|}
\hline \multirow{2}{*}{$\begin{array}{l}\text { Media } \\
\text { Genotypes }\end{array}$} & \multicolumn{4}{|c|}{$\mathrm{S}_{2} \mathrm{D}_{2}$} & \multicolumn{4}{|c|}{$\mathrm{M}_{2} \mathrm{D}_{2}$} & \multicolumn{4}{|c|}{$\mathrm{S}_{2} \mathrm{D}_{2} \mathrm{~K}_{2}$} & \multicolumn{4}{|c|}{$\mathbf{M}_{2} \mathbf{D}_{2} \mathbf{K}_{2}$} \\
\hline & A & B & C & D & A & B & C & D & A & B & C & D & A & B & C & D \\
\hline $\mathrm{G}_{1}$ & 63.95 & 58.88 & 21.54 & 34.95 & 71.10 & 64.79 & 16.40 & 40.11 & 81.53 & 69.30 & 16.27 & 47.05 & 86.91 & 75.04 & 15.02 & 48.0 \\
\hline $\mathrm{G}_{2}$ & 62.86 & 56.71 & 25.02 & 10.04 & 70.00 & 68.90 & 18.12 & 12.12 & 76.24 & 66.15 & 19.00 & 14.48 & 71.57 & 69.59 & 17.08 & 16.32 \\
\hline $\mathrm{G}_{3}$ & 70.55 & 63.64 & 17.98 & 45.12 & 82.06 & 73.06 & 13.85 & 51.14 & 86.15 & 74.13 & 13.92 & 54.88 & 91.18 & 79.94 & 9.65 & 58.22 \\
\hline $\mathrm{G}_{4}$ & 85.01 & 75.03 & 13.14 & 50.03 & 90.04 & 79.78 & 10.81 & 56.16 & 96.0 & 87.41 & 4.94 & 63.28 & 99.10 & 89.55 & 3.39 & 66.85 \\
\hline $\mathrm{G}_{5}$ & 82.75 & 73.24 & 15.18 & 47.28 & 88.02 & 75.03 & 12.11 & 53.76 & 91.76 & 79.89 & 9.23 & 59.36 & 94.95 & 88.20 & 4.20 & 61.28 \\
\hline
\end{tabular}

\begin{tabular}{|c|c|c|c|c|c|}
\hline & & $\mathbf{A}$ & B & $\mathrm{C}$ & $\mathrm{D}$ \\
\hline \multirow[t]{2}{*}{ Media } & SEd & 0.14 & 0.37 & 0.36 & 0.36 \\
\hline & $\mathrm{CD}(0.01)$ & 0.38 & 1.00 & 0.97 & 0.97 \\
\hline \multirow[t]{2}{*}{ Genotpe } & SEd & 0.16 & 0.41 & 0.40 & 0.40 \\
\hline & $\mathrm{CD}(0.01)$ & 0.43 & 1.12 & 1.09 & 1.08 \\
\hline$M \times G$ & SEd & 0.32 & 0.83 & 0.80 & 0.80 \\
\hline interaction & $\mathrm{CD}(0.01)$ & 0.85 & 2.24 & 2.22 & 2.17 \\
\hline
\end{tabular}

\begin{tabular}{|l} 
S2D2 = MS + $2 \mathrm{mg} \mathrm{l}^{-1} \quad 2,4-\mathrm{D}+30 \mathrm{~g}^{-1}$ Sucrose \\
M2D2 $=\mathrm{MS}+2 \mathrm{mg} \mathrm{l}^{-1} \quad 2,4-\mathrm{D}+30 \mathrm{~g} \mathrm{l}^{-1}$ Maltose \\
S2D2K2 = MS $+2 \mathrm{mg} \mathrm{l}^{-1} \quad 2,4-\mathrm{D}+0.5 \mathrm{mgl}^{-1} \mathrm{Kin}+30 \mathrm{gl}^{-1}$ Sucrose \\
M2D2K2 = MS $+2 \mathrm{mgl}^{-1} 2,4-\mathrm{D}+0.5 \mathrm{mgl}^{-1} \mathrm{Kin}+30 \mathrm{gl}^{-1}$ Maltose
\end{tabular}

Callus induction (A), embryogenic callus formation $(B)$, rhizogenic callus formation $(C)$ and regeneration $(D)$.

Table 7: Callus induction per cent from immature embryo at various levels of organic supplements

\begin{tabular}{|c|c|c|c|c|c|c|}
\hline Genotypes & ASD 16 & White ponni & Pusa Basmati 1 & Pusa Sugandh 4 & Pusa Sugandh 5 & Mean \\
\hline$\overline{\mathrm{O}_{1}}$ & $82.55(65.31) \mathrm{f}$ & $81.77(64.73) \mathrm{g}$ & $87.77(69.33) \mathrm{a}$ & $85.10(67.30) b$ & $83.70(66.19) \mathrm{d}$ & $84.18(66.61) a$ \\
\hline $\mathrm{O}_{2}$ & $80.70(63.94) \mathrm{i}$ & 79.85 (63.33)1 & $84.55(66.86) \mathrm{c}$ & $82.62(65.36) \mathrm{e}$ & $81.77(64.73) \mathrm{h}$ & $81.90(64.84) b$ \\
\hline $\mathrm{O}_{3}^{2}$ & $77.10(61.41) \mathrm{m}$ & $72.10(58.12) \mathrm{n}$ & $80.51(63.80) \mathrm{j}$ & $80.00(63.44) \mathrm{k}$ & $79.22(62.88) 1$ & $77.79(61.93) \mathrm{C}$ \\
\hline Mean & $80.12(63.55)$ & $77.91(62.06)$ & $84.28(66.73)$ & 82.57 (65.37) & $81.56(64.60) c$ & $81.29(64.46)$ \\
\hline
\end{tabular}

Values in parantheses are arc sine transformed values

\begin{tabular}{lll}
\hline & SEd & CD (0.01) \\
\hline Genotypes & 0.004 & 0.013 \\
& $(0.003)$ & $(0.010)$ \\
Treatments & 0.004 & 0.010 \\
& $(0.003)$ & $(0.007)$ \\
$\mathrm{G} \times \mathrm{T}$ & 0.008 & 0.022 \\
interaction & $(0.006)$ & $(0.016)$ \\
\hline
\end{tabular}

et al. (2000), Lin and Zhang (2005), Al-Forkan et al. (2004), Agrawal et al. (2006) and Zaidi et al. (2006). The effect of kinetin on callus differentiation could be promotive or inhibitory depending upon the kind and concentration of auxin in the medium, it was observed that addition of $0.5 \mathrm{mg} \mathrm{l}^{-1} \mathrm{~K}$ to the culture media promoted callus induction and embryogenic callus formation and this was in conformation with the results of Brar et al. (1985), Chaliha et al. (1993), Sudha (2000), Khaleda and Al-Forkan (2006), Agrawal et al. (2006). In this study it was seen that maximum percentage of callus induction in $\mathrm{MS}+2$ $\mathrm{mg} \mathrm{l}^{-1} 2,4-\mathrm{D}+0.5 \mathrm{mg} \mathrm{l}^{-1} \mathrm{~K}+30 \mathrm{gl}^{-1}$ maltose compared to $\mathrm{MS}+2.0 \mathrm{mg} \mathrm{l-1} 2,4-\mathrm{D}+0.5 \mathrm{mg} \mathrm{l}-1 \mathrm{~K}+30 \mathrm{gl}-1$ sucrose (Table 4 ) and addition of $100 \mathrm{ml}^{-1}$ coconut milk as organic supplement gave higher callus induction percent with early days (Table 7 and 8).

\section{Regeneration and Hardening}

Many factors such as culture medium, growth regulators, culture environment, explant and genotype of donor are known to influence regeneration of plants. In the present study, regeneration was obtained through callus formation in explants and subsequent formation of shoots and roots. The present study also noted that for embryogenesis, callus induction and root induction the requisite ratio of auxin and cytokinin is high, This was in accordance with Yamada (1967), Sumathi (1992), Sudha (2000) and Lin and Zhang (2005), they reported that cereals require the strong action of auxin to induce callus and to maintain their growth in subcultures. However, for regeneration, it was essential that there can be a decrease in the 2,4-D concentration or the substitution of a weaker 
Table 8: Number of days for callus induction from immature embryo at various levels of organic supplements

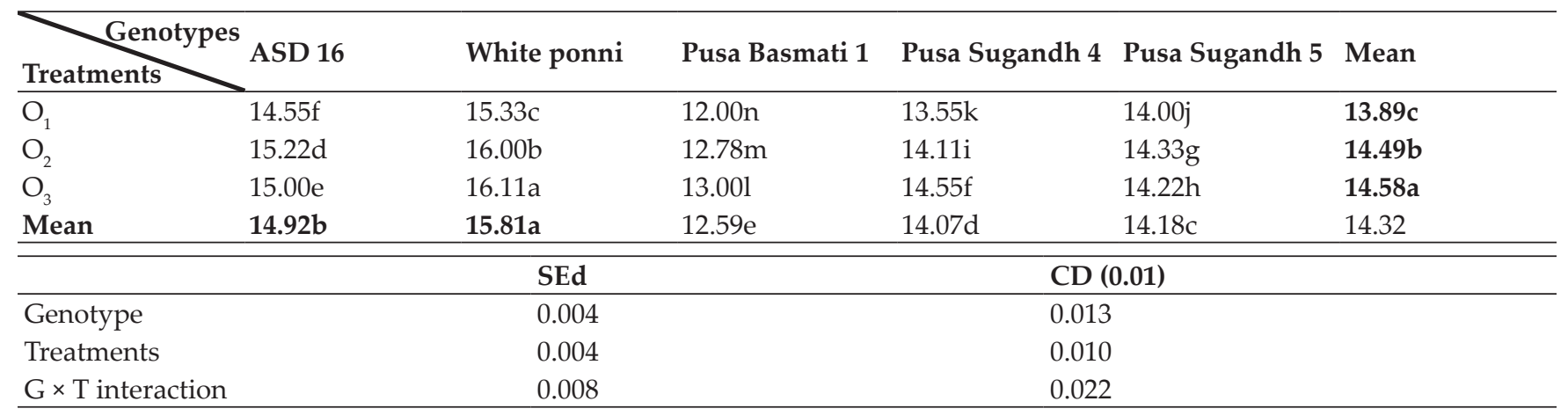

Table 9: Organogenesis per cent from callus of immature embryo at various levels of hormones

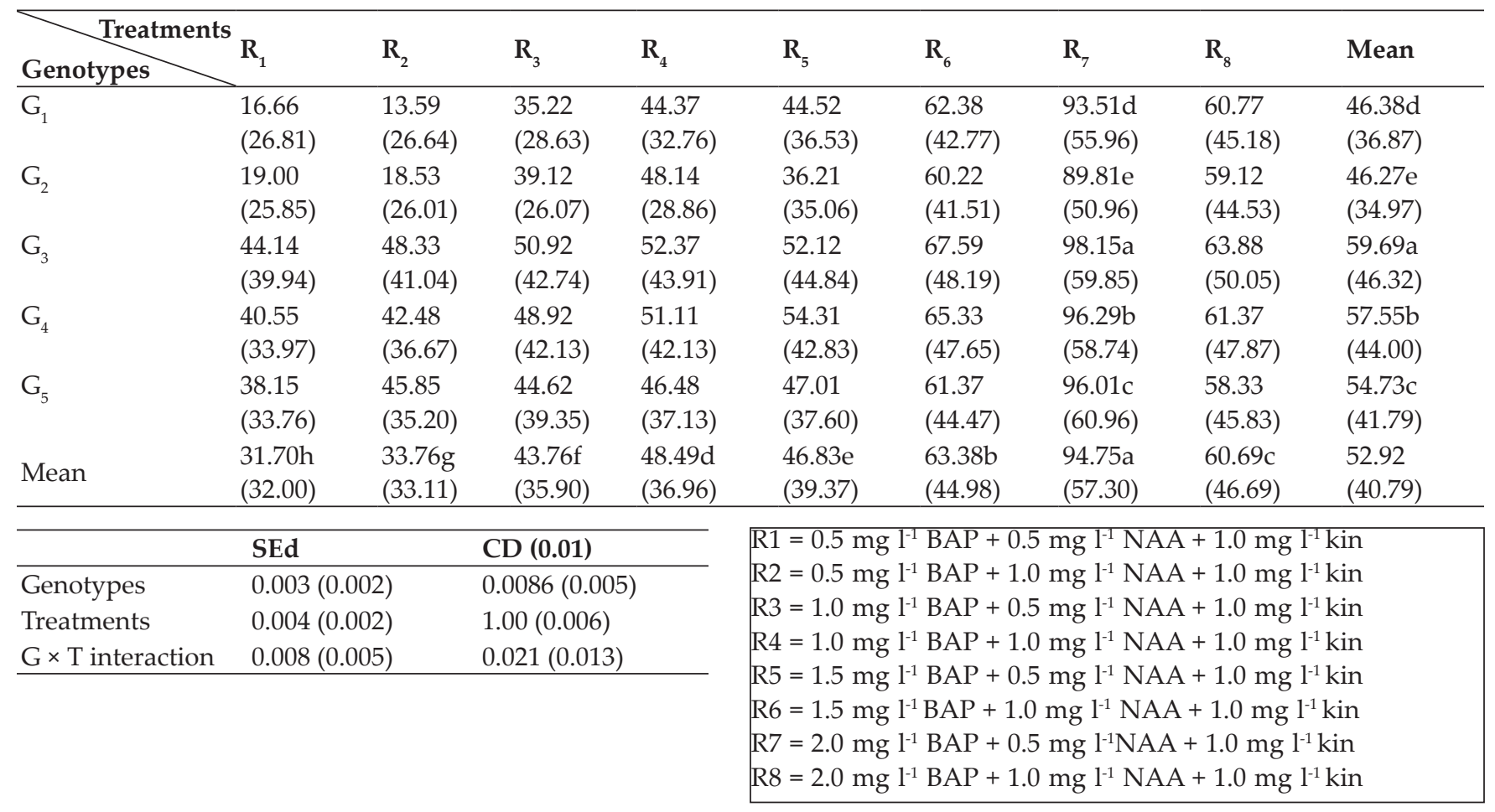

Table 10: Hardening per cent of plant lets from callus of immature embryo

\begin{tabular}{|c|c|c|c|c|c|c|}
\hline $\begin{array}{l}\text { Genotypes } \\
\text { Treatments }\end{array}$ & $G_{1}$ & $\mathrm{G}_{2}$ & $\mathrm{G}_{3}$ & $\mathrm{G}_{4}$ & $\mathrm{G}_{5}$ & Mean \\
\hline$\overline{\mathrm{H}_{1}}$ & $\begin{array}{l}24.78 \\
(29.86)\end{array}$ & $\begin{array}{l}9.40 \\
(17.85)\end{array}$ & $\begin{array}{l}44.19 \\
(41.66)\end{array}$ & $\begin{array}{l}42.83 \\
(40.88)\end{array}$ & $\begin{array}{l}42.12 \\
(40.47)\end{array}$ & $\begin{array}{l}32.66 \mathrm{c} \\
(34.14)\end{array}$ \\
\hline $\mathrm{H}_{2}$ & $\begin{array}{l}25.71 \\
(30.47)\end{array}$ & $\begin{array}{l}11.12 \\
(19.48)\end{array}$ & $\begin{array}{l}57.32 \\
(49.21)\end{array}$ & $\begin{array}{l}55.38 \\
(48.09)\end{array}$ & $\begin{array}{l}51.06 \\
(45.61)\end{array}$ & $\begin{array}{l}40.12 b \\
(38.57)\end{array}$ \\
\hline $\mathrm{H}_{3}$ & $\begin{array}{l}22.08 \\
(28.03)\end{array}$ & $\begin{array}{l}11.85 \\
(20.14)\end{array}$ & $\begin{array}{l}61.38 \\
(51.58)\end{array}$ & $\begin{array}{l}56.63 \\
(48.81)\end{array}$ & $\begin{array}{l}53.8 \\
(47.18)\end{array}$ & $\begin{array}{l}41.15 a \\
(39.15)\end{array}$ \\
\hline Mean & $\begin{array}{l}24.19 d \\
(29.45) \\
\end{array}$ & $\begin{array}{l}10.79 \mathrm{e} \\
(19.15)\end{array}$ & $\begin{array}{l}54.30 \mathrm{a} \\
(47.48) \\
\end{array}$ & $\begin{array}{l}51.61 \mathrm{c} \\
(45.93) \\
\end{array}$ & $\begin{array}{l}48.99 \mathrm{~b} \\
(44.42)\end{array}$ & $\begin{array}{l}37.98 \\
(37.29) \\
\end{array}$ \\
\hline & & \multicolumn{2}{|c|}{ SEd } & \multicolumn{3}{|c|}{ CD (0.01) } \\
\hline Treatments & & \multicolumn{2}{|c|}{$0.050(0.05)$} & \multicolumn{3}{|c|}{$0.132(0.13)$} \\
\hline Genotypes & & \multicolumn{2}{|c|}{$0.62(0.66)$} & \multicolumn{2}{|c|}{$0.17(0.17)$} & \\
\hline $\mathrm{G} \times \mathrm{T}$ interaction & & \multicolumn{2}{|c|}{$0.11(0.11)$} & \multicolumn{2}{|c|}{$0.30(0.29)$} & \\
\hline
\end{tabular}


auxin such as IAA and NAA. Highest regeneration frequency of $(0.33 \%)$ was observed in regeneration media containing $0.5 \mathrm{mg}^{-1} \mathrm{BAP}, 0.5 \mathrm{mg}^{-1}$ Kinetin and $80 \mathrm{mg}-\mathrm{l}$ adenine sulphate in Azucena variety (Dalpat Lal, et al. 2014). Agrawal et al. (2006) reported that green islets formation was more in MS $+1.0 \mathrm{mg}$ $\mathrm{l}^{-1} \mathrm{BAP}+1.0 \mathrm{mg} \mathrm{l}^{1} \mathrm{~K}+0.1 \mathrm{mg} \mathrm{l}^{-1} \mathrm{NAA}$ with the maximum of 57.14 per cent ( Table 9). Among the hardening methods studied, hardening in water followed by mist chamber recorded the highest results (Table 10).

\section{CONCLUSION}

The study revealed that the performance of immature embryo was better than seed for callus induction, emrbyogenic callus formation, rhizogenic callus formation and regeneration. MS media provided superiority over $\mathrm{N}_{6}$ media. All the genotypes performed well in MS compared to $\mathrm{N}_{6}$ media. The best suited carbon source in rice tissue culture was maltose, which had superior effect on callus induction. Enhanced callus induction was obtained with MS medium supplemented with $2.0 \mathrm{mgl}^{-1}$ 2,4$\mathrm{D}+0.5 \mathrm{mgl}^{-1}$ kinetin $+30 \mathrm{gl}^{-1}$ maltose irrespective of explants used. $\mathrm{MS}+2.5 \mathrm{mgl}^{-1} \mathrm{BAP}+0.5 \mathrm{mgl}^{-1}$ $\mathrm{NAA}+1.0 \mathrm{mgl}^{-1} \mathrm{KN}$ gave the highest organogenesis response and regeneration of plantlets. Hardening in mist chamber was recognized as the best method to give the highest per cent of regenerated plant lets. The in vitro protocol reported in this study could be used for indica cultivar (ASD 16, White Ponni, Pusa Basmati 1, Pusa Sugandh 4 and Pusa Sugandh 5) improvement for various traits through tissue culture, genetic transformation and genome edition.

\section{ACKNOWLEDGEMENTS}

Author wish to thank Department of Plant Breeding and Genetics, Agricultural College and Research Institute, Tamil Nadu Agricultural University, Madurai for providing laboratory work facilities. Sincere gratitude goes the management and staff of the Jawaharlal Memorial Fund, New Delhi for kindly providing financial assistance as research grant and fellowship to carry out this work.

\section{REFERENCES}

Abe, T. and Futsuhara, Y. 1985. Theoretical and Applied Genetics, 72(3).
Abiramasundari, N., Shanthi, P., Sassi Kumar, D. and Saraswathi, R. 2015. Callus Induction and Regeneration in Commercial Rice Cultivars of Tamil Nadu. Int. J. Res. Agril. Sci, 1(2).

Agrawal, P.K., Gosal, S.S. and Sidhu, G.S. 2006. Sequential reduction of 2,4-D improves whole plant regeneration from long term maintained calli in some indica cultivars of rice. Oryza, 43(1): 10-15.

Aldemita, R.R. and Hodges, T.K. 1996. Agrobacterium tumefaciens- mediated transformation of japonica and indica rice varieties. Plants, 199: 612-617.

Azhakanandam, K., Mathew, S., McCabe, J., Brain Power, Lowe, K., Cocking, E.C and Davey, M.R. 2000. T-DNA transfer, integration, expression and inheritance in rice: effects of plant genotype and Agrobacterium super virulence. J. Plant Physiol., 157: 429-439.

Brar, D.S., Ling, D.H. and Yoshida, S. 1985. Plant regeneration from somatic from somatic cell cultures of IR varieties. In: Biotechnology International Agricultural Research, IRRI, Las Banos, Philippines, pp. 169-170.

Chaliha, S.J., Baruah, J. and Devi, J. 1993. In vitro plant regeneration from mature seeds in two glutinous rice genotypes of Assam. Oryza., 30: 350-351.

Chen, T.H., Lam, L. and Chen, S.C. 1985. Plant Cell, Tissue and Organ Culture., 4: 51.

Dalpat Lal, H.E., Shashidhar, P.H., Godwa, R. and Ashok, T.H. 2014. Callus Induction and Regeneration from In Vitro anther Culture of Rice (Oryza sativa L.). Int. J. Agri. Env. Biotech., 7(2): 213-218.

Diawuoh, R.G., Klu, G.Y.P., Amoatey, H.M., Out, S.A. and Asare, K. 2017. Callus induction and plant regeneration via leaf segments of three accessions of African rice (Oryza glaberrima Stued.). Int. J. of Agriculture Environment and Biotechnology, 2(5): 2398-2405.

Gomez, K.A. and Gomez, Z.Z. 1984. Statistical procedures for Agricultural Research. John Wiley and Sons. Inc., New York, pp. 680.

Gupta, P.K. 1997. Elements of Biotechnology. Rastogi publications, Meerut, pp. 270.

Hoque, M.N., Rahman, L. and Hassan, L. 2007. Effect of culture media on seed dormancy and callus induction ability of some wild and cultivated rice genotypes. Biotech., 6(1): 61-63.

Hoque, M.E., Mansfield, J.W. and Bennett, M.H. 2005. Agrobacterium-mediated transformation of indica rice genotypes: an assessment of factors affecting the transformation efficiency. Plant Cell. Tiss. Org. Culture, 82: 45-55.

Katiyar, S.K., Chandel, G., Singh and Pratibha, R. 1999. Genetic variation and effect of 2,4-D on in vitro plant regeneration in indica rice cultivars. Oryza., 36(3): 254-256.

Khaleda, L. and Forkan, M.AL. 2006. Genotypic variability in callus induction and plant regeneration through somatic embryogenesis of five deepwater rice (Oryza sativa L.) cultivars of Bangladesh. African J. Biotech., 5: 435-1440. 
Khanna, H.K. and Raina, S.K. 1997. Enhanced in vitro plantlet regeneration from mature embryo derived primary callus of a basmati rice cultivar through modification of nitrate nitrogen and ammonium-nitrogen concentrations. J. Pl. Biochem. Biotech., 6(2): 85-89.

Khush, G.S. 2005. Plant Mol. Biol., 59: 1.

Lakshmi Narayanan, S. 1997. Genetic studies on tissue culture response in indica japonica crosses of rice (Oryza sativa L.). M.Sc., (Ag.) Thesis, TNAU, Coimbatore.

Lee, K., Jeon, H. and Kim, H. 2002. Optimization of a mature embryo based in vitro culture system for high frequency somatic embryogenic callus induction and plant regeneration from japonica rice cultivars. Plant Cell Tiss. Ogan. Cult., 71: 237-244.

Lin, Y.J. and Zhang, Q.F. 2005. Optimizing the tissue culture conditions for high efficiency transformation of indica rice. Plant Cell Rep., 23: 540-547.

Ling, D.H., Chen, W.F., Chen, M.F. and Ma, Z.R. 2011. Plant Cell Reports, 2: 1983, 172.

Monirul Islam, Md., Ahmed, M. and Mahalda, D. 2005. In vitro callus induction and plant regeneration in seed explants of rice (Oryza sativa L.) Research J. Agri. and Bio. Sci., 1(1): 72-75.

Norstog, K.J. 1970. Induction of embryo like structures by kinetin in cultured barley embryo. Develop. Biol., 23: 665-670.

Panse, V.G. and Sukhatme, P.V. 1964. Statistical methods for Agricultural Research Workers. ICAR. New Delhi.

Rabha, M.. Mansur, Ahlam K. Alaila, Rania F. Mohamed, Hamida, Hamad, M.E. 2018. Effect of Different Plant Growth Regulators on Callus Induction from Seeds of Chickpea (Cicer arietinum L.) Int. J. of Agriculture Environment and Biotechnology, 3(1): 99-102.

Rashid, H., Yokoi, S., Toriyama, K. and Hinata, K. 1996. Transgenic plant production mediated by Agrobacterium in indica rice. Plant Cell Rep., 15: 727-730.

Ray, J.K. 1985. Introduction to Botany of the Rice Plant, (Rice Research Institute in India, New Delhi, India), pp. 5.

Saharan, V., Yadav, R.C., Yadav, N.R and Ram, K. 2004. Studies on improved Agrobacterium - mediated transformation in two indica rice (Oryza sativa L.). African J. Biotech., 3(11): 572-575.

Sudha, C. 2000. Identification of best indica type for calls induction and regeneration capacity including hybrid rice parents (Oryza sativa L.) M.Sc., (Ag.) Thesis, TNAU, Coimbatore.
Sun, Z.R., Ni, P.C. and Hung, Z.Z. 1990. Acta Argon. Sin., 16: 123.

Tyagi, H., Rajasubramanian, S. and Dasgupta, I. 2007. Regeneration and Agrobacterium - mediated transformation of a popular indica rice variety, ADT 39. Curr. Sci., 99(5): 678-683.

Tyagi, H., Rajasubramanian, S. and Dasgupta, I. 2007. Regeneration and Agrobacterium - mediated transformation of a popular indica rice variety, ADT 39. Curr. Sci., 99(5): 678-683.

Upadhyaya, G., Sen, M. and Ro, A. 2015. In vitro callus induction and plant regeneration of rice (Oryza sativa L.) var. 'Sita', 'Rupali' and 'Swarna Masuri'. Asian Journal of Plant Science and Research, 5(5): 24-27.

Vasil, I.K. 1987. Developing cell and tissue culture systems for the improvement of cereals and grass crops. J. Plant Physiol., 128: 193-218.

Vasil, I.K. 1988. Progress in the regeneration and genetic manipulation of cereal crops. Biotech., 6: 397-402.

Vasil, I.K. 1995. Cellular and molecular genetic improvement of cereals. In : Current Issues in Plant Molecular Biology. Klurwer Academic Publishers, Dordrecht, The Netherlands, pp. 1-8.

Vinothini, S. 2004. Enhancement of variability in drought tolerant varieties of rice (Oryza sativa L.) Through in vitro mutagenesis. M.Sc. (Ag.) Thesis, A. C \& R. I., Killikulam, TNAU, Coimbatore.

Visarada, K.B.R.S., Sailaja, M. and Sarma, N.P. 2002. Effect of callus induction media on morphology of embryogenic calli in rice genotypes. Biol. Plant., 45: 495-502.

Yamada, Y., Tanaka, K. and Takahashi, E. 1967. Callus induction in rice (O. sativa L.). Proc. Jpn. Acad. Sci., 43: 156-160.

Zaidi, M.A., Narayanan, M., Sardana, R., Taga, I., Postel, S., Johns, R., McNulty, M., Mottiar, Y., Mao, J., Loit, E. and Altosaar, I. 2006. Optimizing tissue culture media for efficient transformation of different indica rice genotypes. Agronomy Res., 4(2): 563-575.

Zhao, J., Zhou, C. and Yang, H.Y. 1999. In vitro development of early pro embryos and plant regeneration via microculture in Oryza sativa. Plant Cell Tiss. Ogan. Cult., 55: 167-174. 
